\title{
Phytoprotection
}

\section{A note on the activity and species composition of sesiids [Lepidoptera: Sesiidae] as measured by pheromone traps and trunk sampling in apple orchards of southwestern Quebec Une note sur l'activité et la composition des espèces de sésies [Lepidoptera : Sesiidae] lors de dépistages à l'aide de pièges à phéromones et d'échantillonnages sur les troncs en vergers de pommiers du sud-ouest du Québec}

\section{Gérald Chouinard, Sylvie Bellerose, Michèle Roy et Charles Vincent}

Volume 87, numéro 3, décembre 2006

URI : https://id.erudit.org/iderudit/015855ar

DOI : https://doi.org/10.7202/015855ar

Aller au sommaire du numéro

Éditeur(s)

Société de protection des plantes du Québec (SPPQ)

ISSN

0031-9511 (imprimé)

1710-1603 (numérique)

Découvrir la revue

Citer ce document

Chouinard, G., Bellerose, S., Roy, M. \& Vincent, C. (2006). A note on the activity and species composition of sesiids [Lepidoptera: Sesiidae] as measured by pheromone traps and trunk sampling in apple orchards of southwestern Quebec. Phytoprotection, 87(3), 131-134. https://doi.org/10.7202/015855ar

\section{Résumé de l'article}

Des adultes mâles et des larves de sésies ont été dépistés dans dix (1989 à 1991), cinq (2000) et deux (2004) vergers de pommiers du Québec. Les adultes ont été capturés à l'aide de pièges Multi-Pher III appâtés de capsules chargées de 99,1 $\%$ d'acétate de Z, Z-3, 13-octadécadiényle et 0,9 \% d'acétate de Z, E plus E, Z-3, 13-octadécadiényle; les larves ont été échantillonnées par examen visuel des troncs. Les mâles adultes capturés de 1989 à 1991 appartenaient aux espèces suivantes : Synanthedon scitula, S. pyri, Podosesia syringae, S. acerrubri, S. fulvipes, S. exitiosa, S. acerni et Sesia tibialis. Seulement 5 des 347 adultes du complexe $S$. scitula/pyri capturés en 2000 appartenaient à l'espèce $S$. pyri. 


\title{
A note on the activity and species composition of sesiids [Lepidoptera: Sesiidae] as measured by pheromone traps and trunk sampling in apple orchards of southwestern Quebec
}

\author{
Gérald Chouinard', Sylvie Bellerose', Michèle Roy², and Charles Vincent ${ }^{3}$
}

Received 2006-04-26; accepted 2007-01-15

PHYTOPROTECTION 87 : 131-134

Adult males and larvae of sesiids were monitored in ten (1989-1991), five (2000) and two (2004) Quebec apple orchards. Multi Pher III traps baited with $99.1 \%$ Z, Z-3, 13-octadecadienyl acetate and $0.9 \%$ Z, E plus E, Z-3, 13-octadecadienyl acetate were used for adults, and trunk sampling was used for larvae. Synanthedon scitula, S. pyri, Podosesia syringae, S. acerrubri, S. fulvipes, S. exitiosa, S. acerni and Sesia tibialis males were captured between 1989 and 1991. Only 5 of the 347 adults of the $S$. scitula/pyri complex captured in 2000 belonged to $S$. pyri.

Key words: Apple trees, pheromone traps, sesiids, Synanthedon pyri, Synanthedon scitula, trunk sampling.

[Une note sur l'activité et la composition des espèces de sésies [Lepidoptera : Sesiidae] lors de dépistages à l'aide de pièges à phéromones et d'échantillonnages sur les troncs en vergers de pommiers du sud-ouest du Québec]

Des adultes mâles et des larves de sésies ont été dépistés dans dix (1989 à 1991), cinq (2000) et deux (2004) vergers de pommiers du Québec. Les adultes ont été capturés à I'aide de pièges Multi-Pher III appâtés de capsules chargées de 99,1\% d'acétate de Z, Z-3, 13-octadécadiényle et 0,9\% d'acétate de $Z$, E plus E, Z-3, 13-octadécadiényle; les larves ont été échantillonnées par examen visuel des troncs. Les mâles adultes capturés de 1989 à 1991 appartenaient aux espèces suivantes : Synanthedon scitula, $S$. pyri, Podosesia syringae, S. acerrubri, S. fulvipes, S. exitiosa, S. acerni et Sesia tibialis. Seulement 5 des 347 adultes du complexe $S$. scitula/pyri capturés en 2000 appartenaient à l'espèce $S$. pyri.

Mots clés : échantillonnage des troncs, pièges à phéromones, pommiers, sésies, Synanthedon pyri, Synanthedon scitula.

The dogwood borer, Synanthedon scitula (Harris), and the apple bark borer, Synanthedon pyri (Harris) [Lepidoptera: Sesiidae], are two lepidopterans indigenous to North America. Dogwood borers (Lepidoptera: Sesiidae) attack a number of woody plant species including dogwood, oak, plum, cherry and apple (Engelhardt 1946; Warner and Hay 1985). According to Woodside (1952), the apple bark borer feeds on apple, pear, mountain ash, hawthorn and serviceberry. In northeastern North America, the dogwood borer became an economically significant pest of apple orchards following the introduction of the Malling and Malling-Merton clonal rootstocks in new plantings. These rootstocks have been linked to the development of burr knots (Warner and Hay 1985).
Female dogwood and apple bark borers readily lay their eggs, and larvae feed and develop in these meristematic tissues on the aboveground portion of the rootstocks (Riedl et al. 1985). The larvae of dogwood borers and apple bark borers feed on the same plant parts (Bergh and Leskey 2003). In Quebec, Parent (1962) reported dogwood borers in a number of orchards at Mont-Saint-Hilaire. Since the 1990s, apple production advisors have reported that a number of dwarf apple tree plantings in southwestern Quebec have sustained severe infestations of sesiids, attributed to $S$. scitula. The current strategy for controlling these infestations involves spraying an insecticide on the trunk in order to suppress the adults and the larvae (Chouinard et al. 2001). Warner and Hay

1. Institut de recherche et de développement en agroenvironnement (IRDA), Saint-Hyacinthe (Quebec), Canada J2S 7B8; corresponding author e-mail: gerald.chouinard@irda.qc.ca

2. Direction de l'innovation scientifique et technologique, Ministère de l'Agriculture, des Pêcheries et de l'Alimentation du Québec (MAPAQ), Complexe scientifique, Québec (Quebec), Canada G1P 3W8

3. Horticulture Research and Development Centre, Agriculture and Agri-Food Canada, Saint-Jean-sur-Richelieu (Quebec), Canada J3B 3E6 
(1985) and Riedl et al. (1985) conducted sampling in some apple orchards in Ontario and New York, respectively, that resulted in the capture of a number of sesiid species. This sampling work gave rise to discussions about the abundance of $S$. scitula in these two regions near the province of Quebec. The studies also showed that $S$. pyri populations in these regions are either below the detection level or too low to cause damage to apple trees. In the state of Georgia (USA), Snow et al. (1985) caught 22 sesiid species in Pherocon 1C traps baited with several pheromone blends. In October 2005, the Canadian Food Inspection Agency also announced that a new species of clearwing moth, Synanthedon myopaeformis (Borkhausen), had been discovered in British Columbia, and surveys conducted in 2006 throughout Canada also revealed its presence in Ontario (Rob Ormrod, personal communication). This note, however, only reports on species composition of sesiids in Quebec apple orchards and on some parameters of their activity as measured by trapping (with $S$. scitula synthetic sex pheromone as a bait) and trunk samplings.

From 1989 to 1991, adult sesiids were monitored in ten apple orchards from southwestern Quebec (Franklin, Hemmingford, Rougemont, Saint-Pauld'Abbotsford, Frelighsburg, Oka, Saint-Joseph-duLac) and from the Quebec City area (Saint-Laurent and Sainte-Famille (Île d'Orléans) and Saint-Antoinede-Tilly). The first four of these orchards were monitored again in 2000. Two Multi Pher III traps (Services Bio-Contrôle, Sainte-Foy (Quebec), Canada) baited with a sex attractant (Scentry Inc., Buckeye, Arizona, USA), composed of $99.1 \%$ Z, Z-3, 13-octadecadienyl acetate and $0.9 \% \mathrm{Z}, \mathrm{E}$ plus $\mathrm{E}, \mathrm{Z}-3,13$-octadecadienyl acetate, were installed in a 5 ha section of each orchard. This choice was based on commercial availability when the experiments started in 1989. The traps were hung in the foliage about $1.5 \mathrm{~m}$ above the ground. They were checked once a week, from early June to mid-October, between 1989 and 1991, and from mid-June to late August in 2000. The sex attractant lures were changed on a monthly basis. All sesiids caught in the traps from 1989 to 1991 were identified to the species level using reference specimens previously identified at Agriculture Canada's Biosystematics Research Institute (currently the Canadian National Collection of Insects, Arachnids and Nematodes) in Ottawa; some specimens were also sent to the above-mentioned Institute to validate identification at the species-level by genitalia analysis (Eichlin and Duckworth 1988). In 2000, sesiids belonging to the $S$. scitula/pyri complex were collected and identified to the species level to determine if the predominance of the dogwood borer over the apple bark borer in New York (Warner and Hay 1985) and Ontario (Riedl et al. 1985) extended to Quebec. Some specimens were sent to the Laboratoire de diagnostic en phytoprotection of the ministère de I'Agriculture, des Pêcheries et de I'Alimentation du Québec (LDPMAPAQ) to validate identification at the species-level by genitalia analysis.

In 2004, two orchards (Dunham and Havelock) from southwestern Quebec with large populations of sesiid larvae on tree trunks were sampled. The time requirement for sampling and identification of larvae did not permit the use of a higher number of orchards. In all, 200 apple trees propagated on dwarfing and semi-dwarfing rootstocks (M.26 or MM.106) were selected using a staggered grid sampling plan in each plot and inspected for sesiid larvae over the first 90 $\mathrm{cm}$ above ground, with special attention given to burr knots. Dead and soft tissues were dislodged or scraped delicately. The larvae removed from infestation sites with soft tweezers were deposited in vials filled with $70 \%$ ethanol and then shipped to LDPMAPAQ for identification of the species using larval morphology (Mackay 1968).

Between 1989 and 1991, eight sesiid species were identified from insects captured in pheromone traps: Synanthedon scitula, S. pyri, Podosesia syringae (Harris), S. acerrubri Engelhardt, $S$. fulvipes (Harris), S. exitiosa (Say), S. acerni (Clemens) and Sesia tibialis (Harris). Adults belonging to the S. scitula/pyri complex were captured in all the orchards (Fig. 1). The first adults were trapped between June 10 and July 23 depending on the orchard and the year. The captures extended into September. On average, the peak level of captures, defined as the maximum number of captures recorded between two checks of the traps, was reached in mid-July, coinciding with an average of 1069 accumulated degree-days (base $5^{\circ} \mathrm{C}$ ).

In the Quebec City region, the first captures were recorded on June 11 and the activity period did not extend beyond the third week of July, with captures lower than in the Montreal region. The highest captures were recorded in commercial orchards rather than in the untreated orchard at Frelighsburg (19891991). The data collected from four orchards in southwestern Quebec, during the period 1989 to 1991, showed a single peak in captures and confirmed that the species of the $S$. scitula/pyri complex are univoltine in Quebec, as Parent reported earlier (1962). Their flight period extends from mid-June into September, with peak activity occurring from the end of June to a few days after mid-July (Fig. 1).

The activity period of adults belonging to the S. scitula/pyri complex, as determined by our monitoring scheme, increased from 1989 to 1991 and varied greatly from one site to another. This variability may be due to numerous factors related to orchard management, presence of wild hosts within or near the orchards, local weather conditions, rootstocks, spray programs as well as possible variation in the quality of the supplied lures.

In 2000, the activity period of the dogwood borer was similar to that observed between 1989 and 1991 for the $S$. scitula/pyri complex, but the peak of captures was delayed to early August as observed for 1990.

These results show that the peak observed in Quebec can occur around between $15 \mathrm{~d}$ earlier and 20 d later than reported in New York (mid-July) for the same sex attractant used in a Pherocon ${ }^{\circledR} 1$ CP sticky trap (Riedl et al. 1985). The Multi Pher III trap kept captured specimens in better condition than the sticky trap, thus facilitating species identification, which was complicated by the low selectivity of the pheromone blend (Bergh et al. 2004, 2006). 


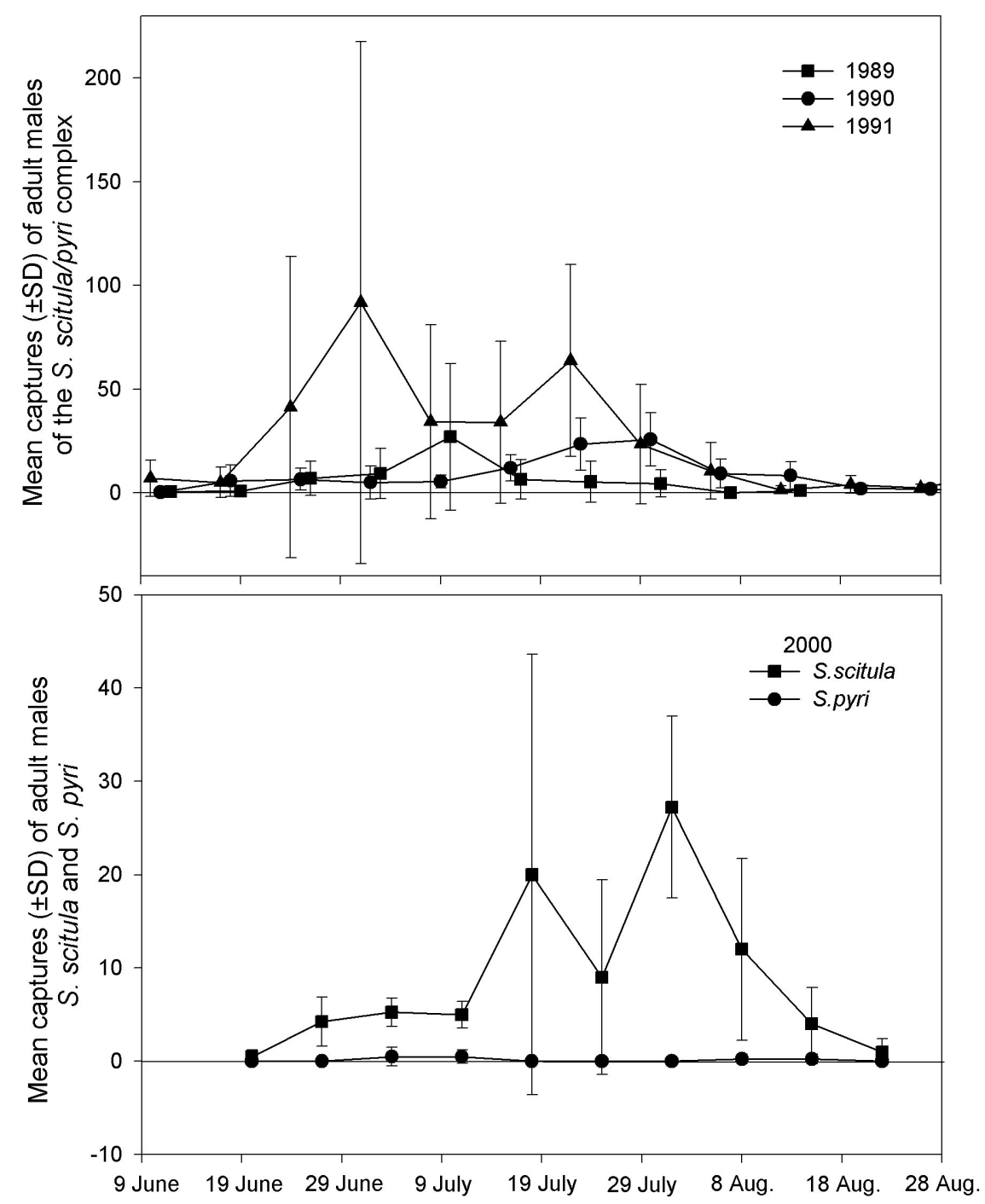

Figure 1. Mean weekly captures per trap ( \pm standard deviation) of sesiids of the Synanthedon scitula/pyri complex, in Multi Pher III traps installed in four southwestern Quebec apple orchards (Franklin, Hemmingford, Rougemont, Saint-Paul-d'Abbotsford) in 1989, 1990, 1991 and 2000.

The infestation levels observed in the two Quebec orchards in 2004 were lower than those reported in New York. Dogwood borer infestation levels of inspected trunks totaled 7\% (Dunham) and 2\% (Havelock) of trunks in 2004. In New York, the percentage of infested trees ranges from $0-100 \%$, depending on the rootstocks and the orchard plots involved (Riedl et al. 1985). In this region, the mean percentage of infested trees was $32-37 \%$ for M.9, MM.106 and M.26 rootstocks, but only $4 \%$ for MM.111.

Only one tree was attacked by the apple bark borer $(0.5 \%$ - five larvae) and only five adults were caught in pheromone traps in 2000 (vs 342 dogwood borers). This was not unexpected since it is a minor pest of burr knots in northeastern North America according to Bergh and Leskey (2003).
The current control recommendation for sesiid borers in heavily infested orchards is to time insecticide sprays with peak adult captures (Chouinard et al. 2001). The use of pheromone traps to monitor sesiid borers would facilitate the application of the recommendation. Recent investigations with new pheromone blends have enhanced the selectivity and attractiveness of dogwood borer pheromones (Bergh et al. 2006; Leskey et al. 2006; Zhang et al. 2005). Other experiments need to be carried out to assess the efficacy and selectivity of these new pheromone formulations and to determine whether they would be sufficiently effective to be used in pheromone traps as part of a recommended monitoring technique suitable to an integrated pest management program. 


\section{ACKNOWLEDGEMENTS}

We thank Ginette Laplante (MAPAQ, Saint-Hyacinthe) and Benoit Rancourt (Agriculture and Agri-Food Canada, Saint-Jean-sur-Richelieu) for their technical assistance, and Claude Ritchot (retired, Laboratoire de Diagnostic, MAPAQ, Saint-Hyacinthe), Mario Fréchette (Laboratoire de Diagnostic en Phytoprotection, MAPAQ, Québec) and P.T. Dang (Agriculture Canada's Biosystematics Research Institute, Ottawa) for the identification of specimens.

\section{REFERENCES}

Bergh, J.C., and T.C. Leskey. 2003. Biology, ecology and management of dogwood borer in eastern apple orchards. Can. Entomol. 135 : 615-635.

Bergh, J.C., T.C. Leskey, and A. Zhang. 2004. Discrimination by male dogwood borer, Synanthedon scitula (Lepidoptera: Sesiidae), among traps baited with commercially available pheromone lures. J. Econ. Entomol. 97 : 344352.

Bergh, J.C., T.C. Leskey, J.M. Sousa, and A. Zhang. 2006. Diel periodicity of emergence and premating reproductive behaviors of adult dogwood borer (Lepidoptera: Sesiidae). Environ. Entomol. 35 : 435-442.

Chouinard, G., Y. Morin, and C. Brodeur. 2001. Lutte contre les insectes et les acariens du pommier. Pages 99-138 in G. Chouinard (éd.), Guide de gestion intégrée des ennemis du pommier. Centre de référence en agriculture et agro-alimentaire du Québec, Quebec.

Eichlin T.D., and W.D. Duckworth. 1988. Sesioidea: Sesiidae. Pages 1-176 in R.B. Dominick et al. (eds.), The moths of America north of Mexico, fascicle 5.1. Wedge Entomological Research Foundation, Washington, DC, USA.
Engelhardt, G.P. 1946. The North American clear-wing moths of the family Aegeriidae. US National Museum Bulletin 190. Smithsonian Institution, Washington, DC, USA.

Leskey, T.C., J.C. Bergh, J.F. Walgenbach, and A. Zhang. 2006. Attractiveness and specificity of pheromone-baited traps for male dogwood borer, Synanthedon scitula Harris (Lepidoptera: Sesiidae). Environ. Entomol. 35 : 268-275.

Mackay, M.R. 1968. The North American Aegeriidae (Lepidoptera): a revision based on late-instar larvae. Mem. Entomol. Soc. Can. 58 : 1-112.

Parent, B. 1962. Observations sur trois nouveaux insectes nuisibles aux pommiers dans le Québec : Thamnosphecia scitula Harris (Lépidoptère : Aegeriidae), Lithocolletis crataegella Clem. (Lépidoptères : Lithocolletidae), et Quadraspidiotus ostreaeformis curtis (Homoptères : Diaspididae). Ann. Soc. Entomol. Qué. 7 : 19-24.

Riedl, H., R.W. Weires, A. Seaman, and S.A. Hoying. 1985. Seasonal biology and control of the dogwood borer, Synanthedon scitula (Lepidoptera: Sesiidae) on clonal apple rootstocks in New York. Can. Entomol. 117 : 13671377.

Snow, J.W., T.D. Eichlin, and J.H. Tumlinson. 1985. Seasonal captures of clearwing moths (Sesiidae) in traps baited with various formulations of 3,13-octadecadienyl acetate and alcohol. J. Agric. Entomol. 2 : 73-84.

Warner J., and S. Hay. 1985. Observation, monitoring and control of clearwings borers (Lepidoptera: Sesiidae) on apple in central Ontario. Can. Entomol. $117: 1471-1478$.

Woodside, A.M. 1952. The apple bark borer. Va. Polytech. Inst. Agric. Exp. Stn. Bull. No. 451.

Zhang, A., T.C. Leskey, J.C. Bergh, and J.F. Walgenbach. 2005. Sex pheromone of the dogwood borer, Synanthedon scitula. J. Chem. Ecol. 31 : 2463-2479. 